PART III

\title{
Political Strategy
}





\title{
Pivot, Hedger, or Partner
}

\section{Strategies of Lesser Powers Caught between Hegemons}

\author{
Yu-Shan Wu
}

Taiwan is strategically situated between the United States and the People's Republic of China (PRC). It is impossible to understand cross-Strait relations without looking into this global strategic context. Although one may not agree with the pessimistic prediction of the power transition theory, namely that the closing gap between the United States and China will result in a titanic clash between the world's hegemon and its challenger, it is nevertheless undeniable that the two strongest nations in today's world have been locked in tense strategic competition. China wants to reclaim its lost central place in the world, a wish that is naturally resisted by today's hegemon, the United States. This is not to deny that Washington and Beijing collaborate in many aspects of their relationship, such as the fight against international terrorism and their joint efforts to deal with climate change. However, as the capabilities of the two giants are getting closer and closer, the relation is strained, with China understandably striving for an equal say on international affairs and the United States hesitant to grant such status to its challenger. The refusal to give China a voting weight in the International Monetary Fund (IMF) that reflects its economic clout is one vivid example, and the competition between the two over the issue of Asian Infrastructure Investment Bank (AIIB) is another. The main geopolitical fault line for Sino-American competition is found in East Asia. Another great strategic conflict in today's world is between the West and Russia over Ukraine. The lesser powers in eastern Europe are in a situation similar to that of their counterparts in East Asia: both are caught in a competition between two great powers.

Given the strained relation between Beijing and Washington and between Moscow and the West, it is interesting to observe the behaviors of the lesser powers 
caught between the two giants on both geostrategic fault lines to see if there is a common pattern. Before we can do this, we need to consult the existing international relations (IR) literature. However, there is a theoretical paucity in this regard. Traditional IR theories focus on the behaviors of greater powers or treat actors as if they have equal capabilities. The international behaviors of small states are understudied, to say the least. Asymmetrical interactions between a great power and a lesser power seldom catch the attention of the theoreticians, let alone the behavioral pattern of a lesser power caught between two competing giants. In the following pages I first develop an analytical framework that specifically addresses this situation and then apply it to the East Asian and eastern European theaters. The core of the analysis is to identify the strategic roles that a lesser country can play between two competing great powers and then, through critical case analysis of Taiwan and Ukraine, to seek to identify the factors that can explain why a specific role is chosen by the lesser power and how that role may change over time. Although the main emphasis is on East Asia, a comparison with eastern Europe is made to add to the analytical depth. It is expected that through the development of this analytical framework we can better understand cross-Strait relations from a theoretical and comparative perspective.

\section{THEORETICAL FORMULATION}

The starting point is obviously the balance-of-power (BOP) paradigm. When facing a rising power, BOP theory predicts a balancing strategy that is either internal (building up military preparedness) or external (forming an alliance). ${ }^{1}$ Traditional BOP theory is modified by Stephen Walt's "balance of threat" theory, in which perceived threat rather than capability is the criterion for the balancing behavior. ${ }^{2}$ For weaker states, "bandwagoning" is added to the toolbox, which prescribes behaviors that conform or do not challenge the core values of the rising power. ${ }^{3}$ However, as both balancing and bandwagoning entail great costs, in the form of either budgetary burden, alliance maintenance, or loss of strategic independence, yet another option presents itself: hedging. Hedging is a two-pronged strategy by which a country both engages and guards against the target country. The "hedger" does not simply adopt a balancing or engagement strategy but employs a mixture of the two. The engagement serves to enhance a friendly relationship with the target country, bring about commercial benefits, and hopefully transform the values and institutions of the target country so that it may stop posing a threat. The balancing serves to provide a security guarantee through either military buildup or an alliance with another great power. Typically engagement happens in the economic realm while balancing happens in the security realm.

Unfortunately, the above theoretical formulations are insufficient to capture the situation of a lesser power caught between two strong nations. First of all, not 
enough attention has been given to small countries and their international behaviors, as most IR theories are about great powers and their interactions. Second, for the literature on small states in world politics, the tendency is to explore their general strategies to survive in a realist world, not to focus on asymmetrical relations. ${ }^{4}$ Third, for those studies that have power asymmetry in mind, the emphasis is typically on a dyad of nations, not a lesser power caught between two strong nations: that is, they focus on the relation between two actors, not three. ${ }^{5}$ When a lesser country finds itself in the middle of great-power competition, it cannot seek advice from traditional IR theories that focus on bilateral relations. A trilateral theory is needed.

The inadequacies of bilateral IR theories can be demonstrated by the interconnectedness of the policies of the lesser power toward the two great powers. Assuming $\mathrm{G}_{1}$ and $\mathrm{G}_{2}$ are the two great powers, and L is the lesser power, we find that L's policy toward $\mathrm{G}_{1}$ is not independent of its policy toward G2. If L considers G1 more powerful than G2, or more of a threat, then it may do a balancing act against G1. Since $\mathrm{L}$ is much weaker than $\mathrm{G} 1$, L's balancing act cannot solely consist of military buildup: it needs to seek an external ally. G2 as a competitor of $\mathrm{G}_{1}$ is a natural choice. However, as $\mathrm{L}$ is also much weaker than $\mathrm{G}_{2}$, the alliance between $\mathrm{L}$ and G2 translates into L's bandwagoning with its ally. Hence L's bandwagoning with $\mathrm{G}_{2}$ is concomitant with L's balancing against G1. In this way, L is both balancing and bandwagoning at the same time, incurring the costs of both strategies. If $\mathrm{L}$ perceives $\mathrm{G}_{2}$ as the main threat, then the opposite will happen, namely L will balance against G2 by bandwagoning with G1. This "coupling of strategies" is captured in figure 7 by L's rightmost and leftmost positions: "Balance against G1 and Bandwagon with G2" and "Balance against G2 and Bandwagon with G1" respectively.

Another strategy that L can adopt is hedging. Again, if we assume that $\mathrm{G}_{1}$ is either more powerful or more threatening, then L may hedge against it. The engagement part of the strategy prescribes building economic ties between L and G1. The balancing part consists of military buildup or external alliance. As L is much weaker than $\mathrm{G}_{1}$, internal balancing is definitely insufficient, necessitating an alliance with G2. This is the second from the rightmost position in figure 7. If G2 is the main target, then L will take the second from the leftmost position. Now L does not need to choose between balancing and hedging toward G1: it can bandwagon. However, since $\mathrm{G}_{1}$ and $\mathrm{G}_{2}$ are locked in fierce competition, bandwagoning with $\mathrm{G}_{1}$ is tantamount to balancing against G2. This leads $L$ to the leftmost position in figure 7 . If G2 is the main threat, and L decides to bandwagon, then it will take the rightmost position and balance against G1. In short, whichever policy taken by L toward G1 (balancing, hedging, bandwagoning), there is a policy corollary for L toward G2. The relations among the G1, G2 and $\mathrm{L}$ are thus intertwined. This shows there is a keen need to develop a trilateral analytical framework. 


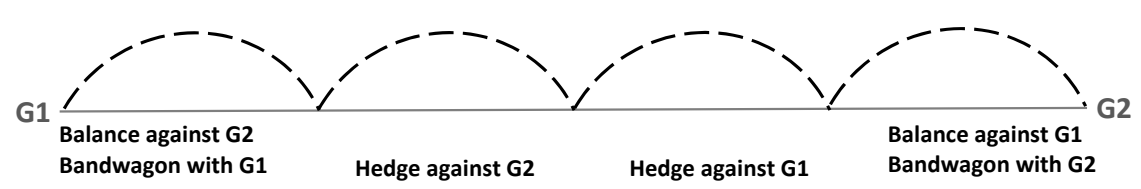

FIGURE 7. Choices of a lesser power placed between two great powers ( $\mathrm{G}_{1}$ and $\mathrm{G}_{2}$ ).

The strategic triangle theory is geared toward analyzing trilateral relations. There are four ideal types of strategic triangle: ménage à trois (three amities), marriage (two enmities and one amity), romantic triangle (two amities and one enmity), and unit veto (three enmities). ${ }^{6}$ In ménage à trois, all three players are "friends." In marriage, two "partners" act against an "outcast." In a romantic triangle, two "wings" court a "pivot." In a unit veto, the players are all "foes" to one another. With the four ideal types of strategic triangle (ménage à trois, marriage, romantic triangle, unit veto), and six roles (friend, partner, outcast, wing, pivot, foe), we can begin analyzing any triangular situation, using the strategic triangle types and roles to describe objectively the structure of the triangular game (see figure 8).

In a strategic triangle, a player considers its amity with other players to be always preferable to enmity. However, the player considers the other two players' mutual enmity to be preferable to their amity. Hence, the most preferable position is that of a pivot, in which the player has friendly relations with the other two players while they are at odds with each other. Interestingly, the pivot's role is not captured in figure 7 .

Now we can integrate the perspectives from both figure 7 and figure 8, integrating the concepts of strategies and triangular roles. ${ }^{7}$ Again we put L's choices on a continuum, as shown in figure 9. L can tilt toward G1 by bandwagoning with it and balancing against G2, which is the leftmost position on the continuum. This would make L a "partner" of G1 in a marriage triangle. Or L can tilt toward G2 by bandwagoning with it and balancing against G1, in the rightmost position on the continuum, which turns L into a partner of G2. L can also modify its stance by moving slightly toward its threat but keeping the principal connection with its ally. L would then "hedge against G1" or "hedge against G2." Either way, L becomes a "hedging partner." If we push L's position to the middle of the continuum, but not so much as to tip it over to the other side, then L becomes the "pivot." A pivot is not principally committed to either of the two great powers but is tilting between them. Hence, we find three roles that a lesser power can play between two competing great powers: partner, hedging partner, and pivot. The three roles are shown in figure 9.

In strategic triangular analysis, pivot is the most desirable position, for it allows $\mathrm{L}$ to maintain amicable relations with the other two players while preventing them from collaborating against it. The pivot can tilt in different directions to 

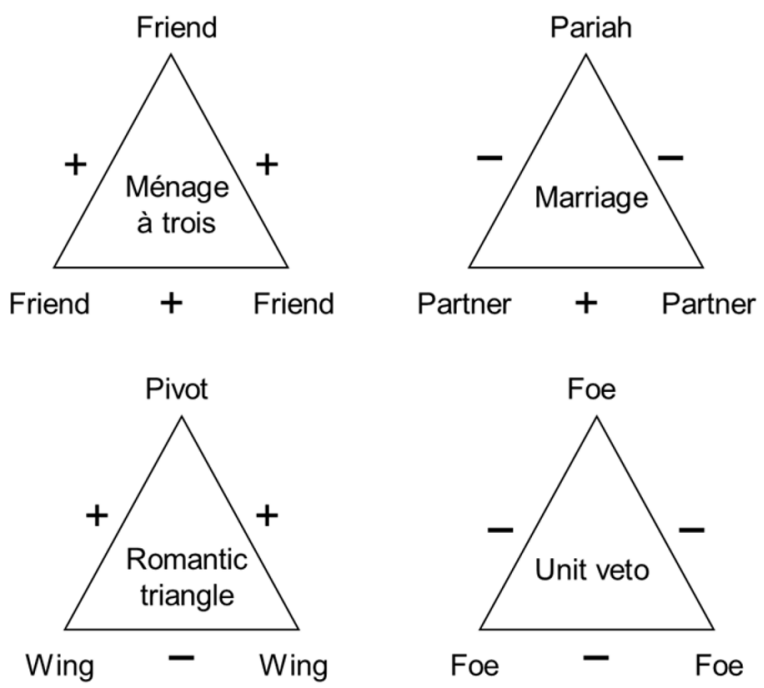

FIGURE 8. Types of strategic triangles.

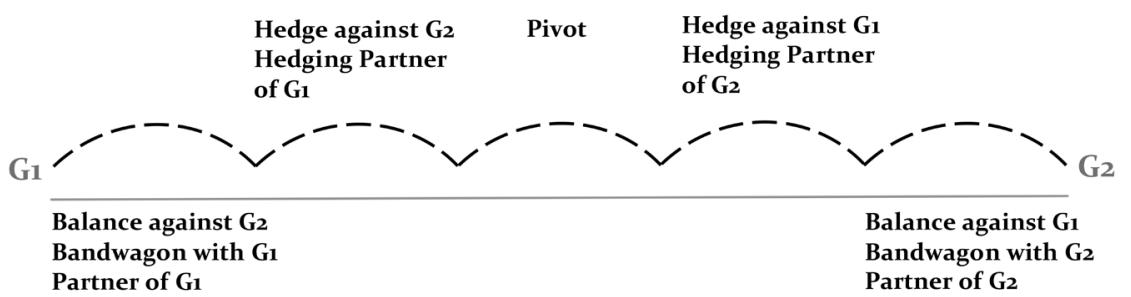

FIGURE 9. Choices and roles of a lesser power placed between two great powers (G1 and G2).

gain concessions from both "wings." However, to play pivot between two strategic giants is an unenviable task for a lesser power. Tilting by pivot naturally causes concern on the part of the wings, eliciting responses that are not necessarily positive. Thus, when $\mathrm{L}$ is tilting between $\mathrm{G}_{1}$ and $\mathrm{G} 2$, either or both of the giants may attempt to coerce $\mathrm{L}$ into their party line instead of courting it. A skillful L may be able to elicit positive concessions but always risks inviting the wrath of the giants and putting itself in a dangerous position. ${ }^{9}$ The role of partner is theoretically less advantageous than pivot, especially for the junior partner, who may be doublecrossed by its senior partner. It thus makes sense for a lesser power caught between two giants to opt for the role of a hedging partner, which entails reasonable security through alliance with one giant, while providing some flexibility of movement 
to elicit courting by the other giant, and possibly some countercourting by its ally, who cannot take the hedging partner for granted.

In the following analysis, I will apply the framework to analyze the relationship between the rising China and its East Asian neighbors, with the strategic competition between Beijing and Washington as the background. I will then use a similar analysis for the European theater. I will likewise put the different policy positions of East European countries toward Russia on a continuum and compare them with their Asian counterparts. The background there is the strategic competition between the US-led West and Russia. Then I will look into cross-Strait relations and the crisis in Ukraine as two critical cases, using the above framework and making comparisons.

\section{RESURGENCE OF OPPOSING ALLIANCES AND POSTURING ON THE FAULT LINE}

During the Cold War, two hierarchically structured alliance systems opposed each other in East Asia. They were the continental system, composed of the Soviet Union, the PRC, North Korea, and North Vietnam (the communist league), and the US-centered, hub-and-spoke maritime system. The power shift in the continental system disrupted the Sino-Soviet pact, as the PRC rose to challenge Moscow's supremacy, while hegemonic stability in the maritime system buttressed the US-led alliance. The division in the continental system offered Washington opportunities to befriend Beijing, and Washington's allies were prompted to act likewise. The tension in competitive rapprochement was absorbed by the hegemonic structure of the maritime system. The result was collective hedging (balancingwith-engagement) against the PRC, with the exception of Taiwan, the Republic of China (ROC). Taiwan was the odd man out because it had a unique relation with mainland China: they claimed sovereignty over each other. The incompatibility of the fundamental goals of the two sides of the Taiwan Strait prevented cross-Strait relations from evolving toward the same direction that began to prevail in the region, namely collective hedging against the PRC. Taiwan's failure to join the chorus was not a sign of its being immune from the structural impetus but a reflection of domestic factors that acted to thwart systemic forces. Those factors, however, proved unable to prevail in the long run. ${ }^{10}$

In the post-Cold War era, the predominance of the United States caused the revival of the Beijing-Moscow nexus, now constructed as an equal partnership. Despite great structural changes, China and Russia are not considered full converts to Western values and institutions and thus are viewed suspiciously by the West. The two continental powers are seen as alien and threatening to the maritime alliance and thus must be guarded against. For Beijing and Moscow, the incessant eastward expansion of NATO and the EU threatens Russia, while the strengthening of 
security ties between Washington and its allies in East Asia puts great pressure on the PRC. Beijing and Moscow understand that the West expects nothing short of their complete conversion, in the form of regime change and peaceful evolution. With China's astronomical rise and Russia's recovery from its post-Soviet malaise, the two continental powers have clung together to form a semialliance, reviving a strategic tie that existed in the 1950s. ${ }^{11}$ Again one finds the continental and the maritime systems confronting each other, just as they did during the Cold War, with the only difference being a shift of the United States' main target from the Soviet Union to the PRC.

Cross-system hedging is inevitable, as this increases the payoff for strategic players. ${ }^{12}$ With China rising rapidly, both the tendency to balance against it and the need to engage it rise for US allies, such as Japan, South Korea, and Australia in the maritime system, causing tension in their domestic politics and their relation with the United States. The maritime system, however, remains robust, as it is sustained by US dominance. ${ }^{13}$ Of particular interest is Taiwan's belated joining of the chorus, under the same systemic forces that disposed its former allies in the maritime system. Because of the issue of overlapping sovereignties, Taiwan was the last to adopt the hedging strategy and reach rapprochement with Beijing as late as 2008, when the Kuomintang (KMT) regained power and the domestic political condition was ready.

From the Cold War to the post-Cold War era, confrontation between the continental and maritime alliances has waxed and waned. Since the turn of the century, it has been on the rise. The first decade of the twenty-first century witnessed milder tension between the two systems than in the 1990s, as the threat of international terrorism rose to prominence and became a primary concern for both the maritime and continental alliances. The pledge of support for the United States in its war on terror by Jiang Zemin and Vladimir Putin in the aftermath of 911 was not merely an exploitation of that dramatic event to improve relations with Washington and to reduce pressure from the West but a reflection of shared interests. ${ }^{14}$ However, the incessant expansion of NATO and the EU into former Soviet bloc coutries and even into the post-Soviet republics, the color revolutions (Georgia in 2003, Ukraine in 2004, Kyrgyzstan in 2005), the Russo-Georgian War (2008), the expediency of amassing political support by whipping up nationalism, and Russia's regained confidence with sustained economic growth led Putin toward greater assertiveness against the West. ${ }^{15}$ For China, territorial disputes with East Asian neighbors allied with the United States, disgruntlement over rigidities in the decision-making process in major international organizations that fail to reflect China's astronomical rise, and a rapid shift of balance in favor of China since the eruption of the global financial crisis in 2008 add to Beijing's increasingly assertive foreign policy. The responses of the West as led by the United States (such as a turn of diplomatic attention "back to Asia," and sanctions against Russian 
aggression) further drove the continental powers together and strengthened the two alliances. Whenever the West was putting pressure on one continental power, the other would never join the chorus but would show "understanding" for the actions by its continental ally; thus there was no Russian criticism of China on Tibet or human rights when Beijing held the 2008 Olympics, a posture that China reciprocated when Russia held the 2014 Sochi Winter Olympics, which were severely criticized by the West. China also scratched Russia's back during and after the Russo-Georgian War by not joining Western criticism and declaring with other Shanghai Cooperation Organization members its support for "the active role of Russia in promoting peace and cooperation in the region" in the Dushanbe Declaration of August 2008. On Syria, neither would endorse sanctions on the Assad regime, and the Russian foreign minister Sergey Lavrov brokered a deal to stop an imminent Western invasion of the country. On Iran both countries advocated negotiations and opposed sanctions in response to Tehran's nuclear program. On Libya both Russia and China resented the West's military intervention against Qaddafi's forces that led to the killing of the dictator, a move legitimated by a liberal interpretation of Security Council Resolution 1973, which merely stated the need for protecting civilians. On Russia's annexation of Crimea, Putin gave special thanks to China for "taking into account the full historical and political context" there. ${ }^{16}$ Under pressure from the West, Russia and China set aside their differences, solved border issues, conducted arms deals regarding state-of-the-art weapons, and intensified energy cooperation. ${ }^{17}$ The two countries formed a Eurasian continental core to resist pressure from the US-led West.

Two geopolitical fault lines thus appeared. They were formed as a result of the pressure building up where "political plates" collide. The two fault lines cut across East Asia and eastern Europe. Lesser powers along these lines bear the pressure of the competing giants: United States plus Europe versus Russia in eastern Europe, and United States versus China in East Asia. The lesser powers have limited choices. They can choose among five options, from top to bottom: partner of the continental alliance (bandwagon with continental, balance against maritime), hedging partner of the continental alliance (bandwagon with continental, hedge against maritime), pivot (noncommittal and tilting in between), hedging partner of the maritime alliance (bandwagon with maritime, hedge against continental), and partner of the maritime alliance (bandwagon with maritime, balance against continental). A partner is fully allied with one great power and distanced from the other. A hedging partner is committed to one camp but engaged positively with the other camp. A pivot holds itself at equal distance from both camps, typically tilting between the two to gain benefits from them.

In figure 10 we present both the East Asian and eastern European fault lines and detail the choices for the lesser powers on those two lines. An East Asian lesser power can choose among the following positions: partner of the PRC, hedging 


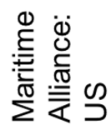

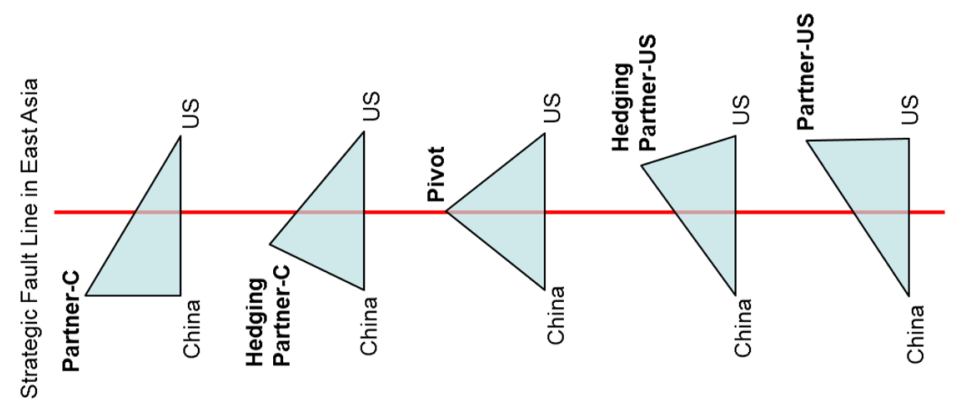

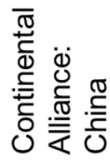

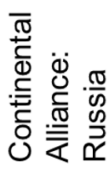

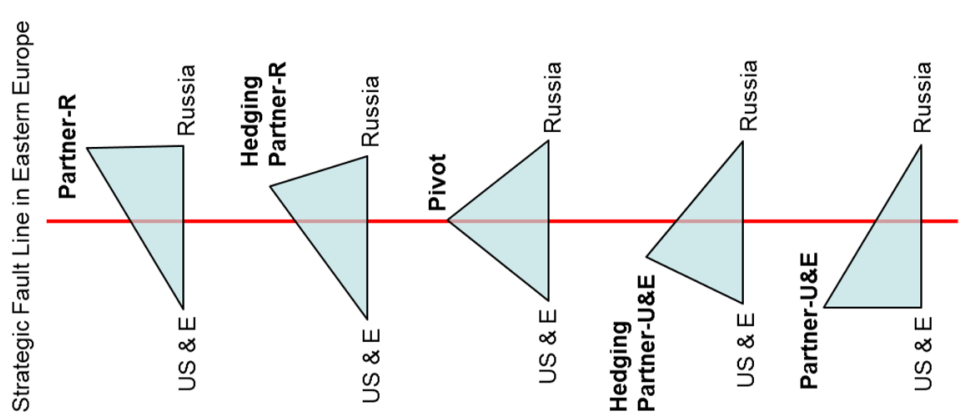

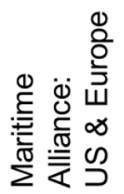

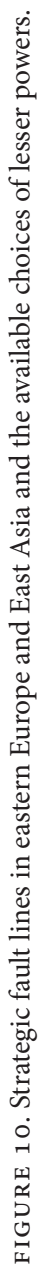


partner of the PRC, pivot, hedging partner of the United States, and partner of the United States. An eastern European lesser power can choose among the following positions: partner of Russia, hedging partner of Russia, pivot, hedging partner of the United States and Europe, and partner of the United States and Europe.

We can also detect the two fault lines by locating the frontline US Air Force operating bases in Eurasia. The bases are located in Asia and Europe in a way to contain the PRC and Russia, or the Eurasian continental core. In East Asia the US operating locations range across Japan, South Korea, the Philippines, Singapore, Thailand, and Malaysia. In eastern Europe, they range across Germany, Poland, Hungary, Romania, Bulgaria, Turkey, and the Arab Peninsula. ${ }^{18}$ Those countries on the border of the American military presence have to make a critical decision about their strategic relation with the United States and the maritime alliance versus their relation with the continental core, particularly when the relation between the two alliances is tense.

At times when there is little conflict between the Eurasian core and the USled maritime alliance, as in the early 200os, when international terrorism was the common enemy and the major concern for both alliances, the frontline countries find themselves in a ménage à trois triangle with the two camps, facing no pressure to take sides. The two fault lines thus look less obvious and relevant. When tensions flare up, as they have since the late 200os, however, frontline countries are forced to take positions under the pressure of the two giants. Different factors in action tilt a particular frontline country to opt for a promaritime, procontinental, or noncommittal position. On the East Asian fault line, Myanmar has been basically a partner of the PRC, although its recent reform and opening to the West tilt it a bit toward being a hedging partner. Cambodia is pro-Beijing in its basic stance. However, Phnom Penh appeals to the international community (i.e., the West) for subsidies and support to overcome the country's tragic experience under the Pol Pot regime. It is a hedging partner of Beijing. South Korea has moved into a pivot position gradually in the East Asian strategic game. ${ }^{19}$ Although it maintains security ties with the United States, its political link with Beijing has been greatly strengthened. China's displeasure with North Korea reduces Pyongyang's drag on PRC-South Korea relations. Beijing and Seoul share historical memories of their victimization by Japan before and during World War II. Furthermore, South Korea is a significant power to reckon with for Beijing in its strategic competition with the United States. Gradually Seoul has become aware of its pivot position and how that position may benefit it. Japan's relation with China has worsened considerably since 2010, primarily because of the territorial dispute over the Diaoyu Islands. However, the very close economic ties benefit both sides and act to mitigate tension in the relationship. Japan remains a hedging partner of the United States, although the balancing part of its strategy has become much more prominent. The Philippines also got into a territorial dispute with Beijing over the islands in 
the South China Sea. That provided enough impetus for Manila to welcome back American military presence in the country. The Philippines is a partner of the United States. ${ }^{20}$

On the East European fault line, frontline countries take different roles in the strategic triangles in which they find themselves. Belarus is a firm partner of Russia, partly because its regime type is unacceptable to the West. Bulgaria has been traditionally close to Moscow and has treasured the special friendship. For Sophia, unlike some of its neighbors, the relation with Moscow is its core and EU/NATO status its hedge. This makes Bulgaria a hedging partner of Russia. The most famous case of pivoting on the East European front is Ukraine prior to the Maidan Revolution, as the country tilted between the EU and the Russia-led Eurasian Economic Union for a better accession deal. After 2014, of course, Kyiv's pivoting led to virtual partition of the country. On the maritime side, Romania is a staunch NATO/EU member that also wishes to keep manageable relations with Russia. Bucharest has been playing the role of a hedging partner of the United States and the EU. The Baltic countries are the firmest allies of the West. Estonia, for example, worries about possible Russian incursion, especially after Moscow's annexation of Crimea, and clings tightly to NATO and the EU. Tallinn is an outright partner of the West.

In the following discussion, two critical cases are examined: Taiwan and Ukraine. They are chosen because they are frontline countries under great pressure that stems from their geopolitical positions on the strategic fault lines in East Asia and eastern Europe. They made different strategic decisions between the competing great powers (the United States and the PRC, the United States/Europe and Russia) over time, with different outcomes. The involvement of ethnic factors complicates the situation, making the lesser power's decision that much more difficult. The continental powers, China and Russia, are more willing to bear costs in order to safeguard their core interests in these cases than when ethnic factors are absent. Finally, dramatic and simultaneous developments on the ground in both cases in the spring of 2014, namely the eruption of the Sunflower Movement in Taiwan and the outbreak of a separatist civil war in Ukraine, make them highly comparable, as these events happened in the same international context.

\section{TAIWAN: FROM SEMIPARTNER TO HEDGING PARTNER}

A major change of Taiwan's frontline position is its shift from semipartner of the United States to hedging partner. Taiwan had been a semipartner of the United States from the end of the 1970s, when the United States derecognized the ROC but committed itself to Taiwan's defense in case of an assault from the mainland, through almost three ensuing decades, during which it was deadlocked in its relation with the mainland and dislodged as a US ally but still under the hegemon's 
protection. ${ }^{21}$ The shift in Taiwan's status was caused by a cross-Strait rapprochement and intensified economic integration after the inauguration of President $\mathrm{Ma}$ Ying-jeou in 2008. As Ma took pains to reassure Washington that Taiwan would be firmly on the US side in the strategic game, and cross-Strait rapprochement did not suggest any political integration or strategic alliance with the mainland, Taiwan turned itself into a hedging partner, doing very much what all the other US allies in East Asia had been doing for decades. This shift, however, was brought about by the alignment of several critical factors that may not hold in the future. It is also more tenuous than it appears, as Taiwan did not change its basic stance toward the United States and mainland China. To understand the 2008 shift of Taiwan's mainland policy and explore its sustainability, a look at the basic structure is in order.

Conflicting forces bear on the cross-Strait relationship, some pushing the two sides together, some pulling them apart. For Taiwan, the former resulted in a "stay" strategy, and the latter in an "exit" strategy. ${ }^{22}$ Those forces are rooted in four structural factors: divided-nation status, power asymmetry, economic integration, and Taiwanese identity. ${ }^{23}$ They are played out in Taiwan's competitive democracy and are constrained by the external limits set primarily by the United States but also partly by Beijing.

Among the four structural factors, divided-nation status and economic integration work primarily to bind Taiwan and mainland China together. Divided-nation status provides a "one-China" constitutional structure and rallies the remnants of Chinese nationalism and ROC patriotism in defense of the status quo. ${ }^{24}$ Economic integration of the two societies is so extensive that any serious disruption of the status quo would impose unfathomable costs on Taiwan, thus deterring the pursuit of "independence." ${ }^{25}$ China and Taiwan's legal and economic ties also make it possible to imagine "ultimate unification" when the conditions are ripe.

Power asymmetry and rising Taiwanese identity produce forces that militate for a unilateral exit from the "one-China" status quo. The increasing power gap between Taiwan and the mainland spells misfortune for Taiwan, the smaller side, which sees its international space constricted by the much stronger opponent; hence the incentive for exiting the game. ${ }^{26}$ Taiwanese identity has deep historical roots, but its rise has more to do with the PRC's monopoly on Chinese identity in international society and the mounting pressure that China puts on Taiwan. Hence power asymmetry and the rise of Taiwanese identity are intrinsically linked. The assertion of an exclusively Taiwanese identity drives Taiwan away from mainland China, which is considered a hostile foreign country. With a shared national identity gone, the basis for unification is undermined. ${ }^{27}$

The two sets of forces are embodied in the two main political camps, "Blue" (favoring more integration with the mainland) and "Green" (favoring more independence), which fight for dominance in Taiwan's competitive democracy. As 
the two camps advocate opposite mainland policies, power turnover at elections naturally brings about policy shifts that may disrupt cross-Strait relations. ${ }^{28}$ Here international factors come in. The US preference to keep the status quo is a powerful force that contains actions by Taiwan's election-driven political leaders. It also of course constrains, or counters, the mainland's move to coerce the island into subjugation. ${ }^{29}$ Given this configuration, one can picture cross-Strait relations as fluctuating along a spectrum with unification, status quo, and independence serving as main marks. Taiwan's position on the spectrum at any given time is set by the result of the last presidential election, which generally reflects the underlying forces of divided-nation status, power asymmetry, economic integration, and Taiwanese identity. The range of possible fluctuations in Taiwan's position over time, however, is set by the preference of the United States, a hegemon that tilts the balance to keep the status quo that best serves its interest. Under these constraints Taiwan's political leaders can fine-tune the island's mainland policy and adjust its position on the East Asian strategic fault line.

In the 2008 presidential campaign, Ma managed to shut down the ideological debate on the identity of the nation (a losing battle for the KMT) and instead direct popular attention to Taiwan's economy, which had considerably slowed down since 2000, when the Democratic Progressive Party (DPP) had captured power. From 2001 to 2008 , Taiwan's economic growth rate averaged 3.8 percent, compared with a 6.2 percent rate in the previous decade, when the KMT was in power. The unemployment rate more than doubled from an average of 2.1 percent in the $1990 \mathrm{~s}$ to 4.4 percent from 2001 through 2008 . With the identity issue and pursuit of de jure Taiwan independence "delegitimated" in public debate and with economic issues in the ascendancy, Ma was able to win the 2008 and 2012 presidential elections by demonstrating to the people that only the KMT could smoothly handle cross-Strait relations, which were a prerequisite for the growth and development of Taiwan's economy. Even though Taiwanese identity continued to grow under Ma's watch, and power disparities across the Taiwan Strait widened rapidly, Ma was able to play the economic card effectively to win reelection, thus sustaining the party's "stay" strategy. However, the status quo was seriously shaken in 2014.

Given the framework of cross-Strait relations mentioned above, changes can be expected if the main pillars of the status quo begin to shake. Following Ma's shift to the economy, the DPP put proindependence rhetoric on the back burner and began challenging Ma's main argument that economic integration with the mainland was good for Taiwan. From 2008 to 2014, Taiwan's economy continued to grow slowly at an average of 3.8 percent, while unemployment surged to 4.7 percent. Distribution has become a serious issue, affecting particularly the young generation. The Oshima Index, which gauges the gap between the top 20 percent of households' income and the bottom 20 percent, rose from 6.03 in 2000-2007 to 6.16 in $2008-14$. Part of the economic malaise was obviously caused by the 
international financial crisis, and part was the result of the inefficiencies of the government. The Economic Cooperation Framework Agreement (ECFA) with the mainland might have helped, but the overall economic picture was bleak. Now Ma cannot claim that cross-Strait integration can invigorate Taiwan's economy. His critics have instead pointed to the adverse effect of close economic ties with mainland China.

Under these circumstances students and young demonstrators broke into the Legislative Yuan and staged a three-week occupation of the parliament in March and April of 2014. The event was touched off by the popular uproar against a bill that would liberalize service trade across the Taiwan Strait as part of the ECFA arrangement. The bill suffered from the DPP's legislative blockade for several months, and the KMT rammed it through the committee stage. The Sunflower Movement wanted to torpedo the bill and kill future agreements that would further cross-Strait integration. The apparent rationale for the movement was to redress procedural injustices, but the bottom line was the anti-China sentiment among the most economically vulnerable and politically vocal. Ma's economic advantage was turned upside down. Since he had so successfully defused ideological debate and concentrated national attention to the economy, his administration was ill prepared to fight political opponents who equipped themselves with incisive economic arguments. With Chinese identification (and even dual ChineseTaiwanese identification) falling precipitously under his watch, and the economy failing to deliver on his promises, Ma found his initiative to improve cross-Strait relations balked. The political wind began to blow in the other direction. The KMT suffered major losses in both the 2014 local elections and the 2016 presidentialand-parliamentary elections. The DPP's presidential candidate Tsai Ing-wen won a landslide victory in 2016, and the DPP captured for the first time a majority in the parliament. Under Tsai, Taiwan swiftly adjusted its relationship with the mainland. By refusing to recognize the " 1992 Consensus" that Taiwan and the mainland make up one China while agreeing to differ on which government is its legitimate representative, Tsai at one stroke undermined the basis of cross-Strait rapprochement. Beijing began its retaliation, and Taiwan tilted further toward the maritime alliance.

With regard to the role that Taiwan plays on the East Asian strategic fault line, the crux of the matter is whether Taiwan is able, or willing, to sustain its rapprochement with mainland China. With that hedge in place, Taiwan is a hedging partner of the United States. Without it, it will simply play the role of a partner, though more a semipartner. The KMT and the DPP are representing these two roles, based on their positions on the 1992 Consensus and their willingness or unwillingness to pay lip service to the "one-China" principle that Beijing uses as a litmus test to determine amity or enmity. With the KMT or the DPP in power, a 
basic position on the 1992 Consensus and the one-China principle will be taken, which then determines whether the rapprochement hedge is kept in place. That puts Taiwan in the role of either a hedging partner or a semipartner of the United States on the East Asian strategic fault line.

\section{UKRAINE: TRAGIC PIVOT}

Many East European countries are like Taiwan in being situated on a strategic fault line. The lesser countries in both cases are threatened by a powerful neighbor (mainland China and Russia), yet there are very strong economic links between them and the behemoth (in the form of trade/investment and energy dependence). Both seek a security guarantee from the United States, with varying degrees of success. There have been occasions in the two cases when leaders took defiant balancing acts against the strong power (as did Chen Shui-bian and Georgia's Mikheil Saakashvili). Those acts were often followed by rapprochement gestures (as made by Ma Ying-jeou and Bidzina Ivanishvili).

Among the East European countries, Ukraine is the most comparable with Taiwan. Both have a well-developed region-based political cleavage (North vs. South in Taiwan, North and West vs. South and East in Ukraine) that harks back to the (sub)ethnic and linguistic divisions in the population and their different historical memories. Taiwan has been plagued by the identity rift between the Chinese and dual Chinese-Taiwanese identifiers on one side and exclusively Taiwanese identifiers on the other side. In Ukraine the division is between Ukrainian nationalists on one side and ethnic Russians plus Russian speakers on the other side..$^{30}$ Different camps in Ukraine hold diametrically different positions toward Russia and expect relations with Russia to evolve in opposite directions. The Chinese identifiers and dual identifiers in Taiwan accept the possibility of unification with the mainland if the conditions are ripe. The exclusively Taiwanese identifiers regard mainland Chinese as an alien nation and China as a foreign country. The same can be said of East and West Ukrainians with regard to their affinity for or antagonism toward Russia. In both cases certain industries and regions are more integrated with the strong neighbor than others, resulting in different degrees of economic vulnerability. Language is a touchy issue, starting with whether Taiwanese can be termed a southern Fukien dialect and whether Ukrainian and Russian are basically the same language. The most telling similarity between the two countries is that their different political camps took turns winning elections and governing the nation, leading to wide fluctuations in their policies toward the strong neighbor and the West.

In Ukraine, as in Taiwan, contending forces advocate diametrically opposite policies toward their great-power neighbor. Ukraine was a founding member of 
the Commonwealth of Independent States and kept close institutional ties with Russia after the breakup of the Soviet Union. It was part of the Russian Empire and then the Soviet Union for hundreds of years. The ethnic, cultural, and historical bonds between Ukraine and its eastern neighbor are strong, especially in the southern and eastern parts of the country. Its modern economy was created and institutionalized as an integral and complementary part of the Russian Federation's. Soviet economic plans integrated Ukraine and Russia, the two most populous Soviet republics, to an extent beyond the integration between Russia and other parts of the Soviet Union. Ukraine's market and energy dependence on Russia is overwhelming, making any disruption of those economic ties an unbearable loss to Ukraine. ${ }^{31}$ On the other hand, ever since the independence of Ukraine Kyiv has been building a new nation by inculcating Ukrainian nationalism and targeting Russia as its main "other." Political competition in this nascent democracy necessarily intensified ethnic mobilization. Russia's rise and increasing assertiveness under Putin provided strong impetus for the advance of a Ukrainian nationalism that sees Russia as a looming threat to the identity and integrity of Ukraine. In short, legal and cultural bonds with Russia and deeprooted economic integration act to draw Ukraine to its eastern neighbor, while rising Ukrainian nationalism and increasing power asymmetry drive the two Slav countries apart.

Since the democratic transition, Taiwan has witnessed power transfers between the Blue and Green camps, including a Blue president who changed his political hue during and after incumbency (Lee Teng-hui). The same can be said of Ukraine: the first popularly elected president Leonid Kravchuk, a vehement Ukrainian nationalist, was replaced by the pro-Russian Leonid Kuchma in 1994; Kuchma was succeeded by the pro-Western Orange Revolution leader Viktor Yushchenko in 2004; Yushchenko was defeated by Viktor Yanukovych from the East in the latter's political comeback in 2010; and Yanukovych fled the country and was succeeded by the Orange Revolutionary business tycoon Petro Poroshenko after the Russian annexation of Crimea in 2014. ${ }^{32}$ With each power turnover, the country's policy toward its huge eastern neighbor changed dramatically.

Yanukovych was deprived of his presidency in the heyday of the Orange Revolution, being accused of vote rigging. ${ }^{33}$ After he won the 2010 presidential election, Ukraine embarked on a policy shift toward the East. However, despite his pro-Moscow orientation Yanukovych began tilting between Russia and the EU in 2013 in an effort to elicit the best terms for Ukraine, which was on the verge of an economic crisis. ${ }^{34} \mathrm{He}$ showed willingness to sign an association agreement with the EU as a first step toward joining that organization. This unexpected tilt caused great concern in Putin, who then applied carrots (a pledge to purchase US $\$ 15$ billion of Ukraine's government bonds and lower the price for Russian gas by one-third) and sticks (disruption of Ukrainian exports to Russia) to change 
Ukraine's course. In this way, Russia and the EU found themselves in a bidding war for Ukraine. ${ }^{35}$ Finally Yanukovych backed off from signing the association agreement with the EU on November 21 and embraced Putin's offer. In a sense, Yanukovych was successful in turning the country from a partner of Russia to a genuine pivot and taking advantage of that position.

However, the president's successful maneuvering on the international stage was not appreciated by the Ukrainian population, especially the western part of the country, who saw their rising hopes of joining the EU dashed by Yanukovych's unabashed manipulation. Hence came the Maidan Revolution, in which protracted confrontation between the demonstrators and police evolved into a semi-civil war in the heart of the capital Kyiv. After the shooting deaths of about one hundred demonstrators on February 2014, the situation spiraled out of control. Pressure from the West mounted, the Maidan revolutionaries prepared for a showdown, and Yanukovych fled for his life. Moscow swiftly declared this a Western-supported coup and moved to annex Crimea, where ethnic Russians constitute a clear majority of the population. Then came the separatists' capture of the cities and towns of a major portion of Luhanst and Donetsk, the two easternmost provinces of Ukraine that border on Russia with the highest percentage of ethnic Russian residents and Russian-speaking population. From Russia's point of view, the West and the pro-Western Ukrainians had changed the rules of game: instead of competing with the pro-Russian East in elections, they now expelled "Moscow's" president and grabbed power in a staged "revolution." As a result, Russia did not have to abide by the broken rules. Hence the annexation of Crimea and the launch of people's republics in Luhansk and Donetsk. The Ukrainian civil war has raged on, Crimea seems lost forever, and the two people's republics are becoming areas of "frozen conflict," just like Transdniestria, Nagorno-Karabakh, South Ossetia, and Abkhazia. The alternation of power holders in the past has been replaced by virtual partition of the country.

Ukraine played pivot tragically. The wide swings that Yanukovych made between Russia and the West proved too much for his countrymen and for the two giants. The result was the virtual partition of the country and chronic economic crisis. During the process, Russia paid a dear price, and so did some of the European countries, at a time of great economic difficulties in Europe. The Russian people, however, have shown their willingness to stand by their leader in a showdown with the West over Russia's core interest: strategic areas in Luhansk and Donetsk, control of Sevastopol, and protection of ethnic Russians and Russian-speaking people in East Ukraine. ${ }^{36}$

At the time when the crisis in Ukraine evolved, Taiwan experienced its Sunflower Movement. The two crises were not directly related, but they were rooted in similar strategic conditions: a lesser country's controversial policy amid competition between two great powers on a strategic fault line. A significant portion 
of the society found the government's policy toward the huge neighbor unacceptable, and they revolted, although in different ways and with different intensity. Yanukovych's turnabout caused greater disturbance, for it was on a fundamental issue of Ukraine's direction and identity-join either the EU or the Russian-led EEU-whereas the service trade liberalization agreement was merely a part of a comprehensive economic deal between Taiwan and the mainland. The actions of the Maidan revolutionaries and the response from Yanukovych's government were much more violent than those of the Sunflower students and the Taipei police. Nor did the People's Liberation Army take any actions like those of the Russian military. Nevertheless, the root cause of the two crises is similar: the tension in the position of a lesser power caught between competing giants. The fact that in Taiwan and Ukraine conflicting national identities were involved added to the tension. From Taiwan's point of view, it is imperative to avoid the Ukrainian scenario. Many lessons can be learned here.

\section{CONCLUSION}

This chapter starts with the making of a list: strategic choices of a lesser country caught in a great-power competition. Partner, hedging partner, and pivot are identified as the choices. The list is based on traditional IR theories, the notion of power asymmetry, and the typology of the strategic triangle. A subsequent geopolitical analysis asserts the resurgence of the conflict between the maritime alliance and the continental alliance in the post-Cold War era. Their conflict brought about two strategic fault lines, one cutting across East Asia and the other eastern Europe. Taiwan sits on the East Asian fault line, and its relation with mainland China is a case of a lesser country caught between competing great powers and choosing from a short policy list. The grand policy shift toward rapprochement with the Chinese mainland under Ma Ying-jeou was made possible by the president's strategy of shutting down debate on identity conflict and focusing on the economy. Taiwan's subsequent undesirable economic performance then turned Ma's greatest asset into a crippling liability. Taiwan's mainland policy is the key to the role it plays on the East Asian strategic fault line: hedging partner (with rapprochement) or semipartner (without rapprochement). In comparison, Ukraine's policy toward Russia and the EU is presented to show how Yanukovych led the country from the role of hedging partner of Russia to the role of pivot, with tragic consequences. The swings that Yanukovych and his successor made went beyond the pale of acceptable maneuvers for the Ukrainians and the great powers. Ukraine's tilting caused the country's virtual partition. This suggests that pivot is a less safe position than hedging partner or partner for a lesser country caught between two competing giants and that decisions on fundamental issues (such as the one of joining the 
core organization of either camp) may act as catalysts for great domestic unrest and international intervention. Once the country is forced to make a decision of placing itself firmly in the camp of either great power, ambiguity is lost, causing a vehement reaction from the losing side. The result may be democratic breakdown, domestic revolution, military intervention, territorial partition, and prolonged economic crisis. Keeping away from such fundamental choices seems to be a sine qua non for a pivot player.

To put cross-Strait relations in the category of lesser powers' interactions with two competing giants on the East Asian and East European strategic fault lines serves several purposes. First, it advances IR theories in areas they overlook: small countries, asymmetrical relations, triangular interaction, and geostrategic analysis. Second, it deepens our understanding of cross-Strait relations through a theoretical perspective offered by the above analytical framework. Third, it makes structural comparison possible between Taiwan and other lesser powers along the East Asian fault line, as well as the frontline countries in eastern Europe, thus deepening our understanding of all the cases compared. The discussion and comparison of cross-Strait relations and crisis in Ukraine are thus made possible. In future research, the factors and mechanisms that affect the decisions of these lesser powers vis-à-vis two giants can be fully identified and tested in multiple case studies with a comparative perspective, thus deepening our understanding of lesser countries' strategic decisions in great-power competition more generally.

\section{NOTES}

1. Kenneth N. Waltz, Theory of International Politics (Reading, MA: Addison-Wesley, 1979).

2. Stephen Walt, The Origins of Alliances (Ithaca, NY: Cornell University Press, 1987).

3. For the concept of bandwagoning, see Stephen Walt, "Alliance Formation and the Balance of World Power," International Security 9, no. 4 (1985): 3-43; and Randall Schweller, "Bandwagoning for Profit: Bringing the Revisionist State Back In," International Security 19, no. 1 (1994): 72-107. However, bandwagoning typically is not considered a productive option in a realist world. For the limited usefulness of bandwagoning, see Walt, Origins of Alliances, 33; and John J. Mearsheimer, The Tragedy of Great Power Politics (New York: W. W. Norton, 2001), 139.

4. Take, for example, David Vital, The Inequality of States: A Study of the Small Power in International Relations (Oxford: Clarendon Press, 1967); Niels Amstrup, “The Perennial Problem of Small States: A Survey of Research Efforts," Cooperation and Conflict 11, no. 2 (1976): 163-82; Efraïm Inbar and Gabriel Sheffer, eds., The National Security of Small States in a Changing World (London: Frank Cass, 1997); Jeanne A. K. Hey, ed., Small States in World Politics: Explaining Foreign Policy Behavior (Boulder, CO: Lynne Rienner, 2003); Christine Ingebritsen et al., eds., Small States in International Relations (Seattle: University of Washington Press, 2006); and Clive Archer, Alyson J. K. Bailes, and Anders Wivel, eds., Small States and International Security: Europe and Beyond (Oxon: Routledge, 2014). 
5. One example is Brantly Womack's analysis of the asymmetrical relation between China and Vietnam, from which he develops a general theory on interactions between a strong and a lesser power. See Brantly Womack, China and Vietnam: The Politics of Asymmetry (Cambridge: Cambridge University Press, 2006). There is also a huge literature on how China's neighbors deal with the rising hegemon; see, for example, Kokubun Ryosei and Wang Jisi, eds., The Rise of China and a Changing East Asian Order (Tokyo: Japan Center for International Exchange, 2004), Part III; David C. Kang, China Rising: Peace, Power, and Order in East Asia (New York: Columbia University Press, 2007), Part II; David M. Lampton, The Three Faces of Chinese Power: Might, Money, and Minds (Berkeley: University of California Press, 2008), 164-206; Li Mingjiang, ed., China's International Relations in Asia, vol. 4, East Asia Responds to a Rising China (Oxon: Routledge, 2010); Herbert S. Yee, China's Rise: Threat or Opportunity? (Oxon: Routledge, 2011).

6. Lowell Dittmer, "The Strategic Triangle: An Elementary Game-Theoretical Analysis," World Politics 33, no. 4 (1981): 485-515.

7. The strategic triangle theory, or any other analytical framework geared toward trilateral relations, cannot be directly applied to our situation here (i.e., lesser country caught between competing great powers), for it fails to address power asymmetry. A typical example is Gerald Curtis, Ryosei Kokubun, and Wang Jisi, eds., Getting the Triangle Straight: Managing China-Japan-US Relations (Tokyo: Japan Center for International Exchange, 2010).

8. $\mathrm{L}$ is still a partner in a strategic triangle in the sense that it keeps a principal security tie with another actor. However, as it hedges (engages while also balancing) against the third actor, it becomes a hedger. Since its relation with the other partner is the principal one, we shall call it a "hedging partner." The role of a hedging partner cannot be clearly shown in the traditional diagram of a marriage triangle, as hedging entails not simple amity $(+)$ or enmity $(-)$ in the hedger's relation with the other two players but a combination of the two in the same relationship. A hedger decisively tilts toward its partner but flirts with the outcast.

9. Thus it is more convenient for a strong nation to play pivot, as the United States did when tilting between the Soviet Union and China in the early 1970s, a role strongly advocated by Henry Kissinger. The bottom line is that a wing is more likely to court the pivot than to coerce it if the pivot is a powerful actor. When a small country plays pivot between two giants, it is more like a tail wagging two dogs. For Kissinger's advocacy of the pivot, see Henry Kissinger, White House Years (Boston: Little, Brown 1979), 165.

10. For a discussion of the shift in East Asia's alliance systems and Taiwan's peculiar role, see YuShan Wu, "Power Shift, Strategic Triangle, and Alliances in East Asia," Issues and Studies 47, no. 4 (2011): $1-42$.

11. Several symbolic highwater marks can be cited here: the Sino-Soviet Treaty of Friendship, Alliance and Mutual Assistance, signed in 1950, which ushered in the continental military alliance; the Sino-Russian Treaty of Good Neighborliness, Friendship, and Cooperation, signed in 20o1; and the Shanghai Cooperation Organization, launched in the same year, which resumed a semialliance between the two continental countries and Sino-Russian joint naval drills presided over by the two heads of state Xi Jinping and Vladimir Putin in 2014.

12. In a triangular strategic game, it is always preferable to develop amicable relations with the other two players while guarding against their collaboration against oneself.

13. For how Japan both engaged and hedged against China, and how this was done under tight security bondage between Tokyo and Washington, see Glenn D. Hook et al., Japan's International Relations: Politics, Economics and Security (Oxon: Routledge, 2005), 196-202.

14. For Russia's foreign policy turnabout, see Andrei P. Tsygankov, Russia's Foreign Policy: Change and Continuity in National Identity, 2nd ed. (Lanham, MD: Rowman and Littlefield), 129-70.

15. Yu-Shan Wu, "Russia’s Foreign Policy Surge: Causes and Implications," Issues and Studies 45, no. 1 (2009): 117-62. 
16. In his presidential address to the Russian Parliament (Federal'noe Sobranie), heads of Russian regions, and civil society representatives in the Kremlin on March 18, 2014, Putin stated, "We are grateful to the people of China, whose leaders have always considered the situation in Ukraine and Crimea taking into account the full historical and political context." Vladimir Putin, "Address by President of the Russian Federation," March 18, 2014, http://en.kremlin.ru/events/president/news/20603.

17. For the development of Sino-Russian relations under pressure from the West, see James A. Bellacqua, ed., The Future of China-Russia Relations (Lexington: University Press of Kentucky, 2010); Natasha Kuhrt, Russian Policy towards China and Japan (New York: Routledge, 2007); Robert Legvold, ed., Russian Foreign Policy in the Twenty-First Century and the Shadow of the Past (New York: Columbia University Press, 2007); Bobo Lo, Russian Foreign Policy in the Post-Soviet Era: Reality, Illusion and Mythmaking (New York: Palgrave Macmillan, 2002); Bobo Lo, Axis of Convenience: Moscow, Beijing and the New Geopolitics (Washington, DC: Brookings Institution Press, 2008); Niklas Swanström, "Transformation of the Sino-Russian Relationship: From Cold War to the Putin Era," in Eurasia's Ascent in Energy and Geopolitics: Rivalry or Partnership for China, Russia and Central Asia?, ed. Robert Bedeski and Niklas Swanström (Oxon: Routledge, 2012); and Yu-Shan Wu, "Russia and China Security," in Routledge Handbook of Chinese Security, ed. Lowell Dittmer and Maochun Yu (Oxon: Routledge, 2015).

18. Lynn E. Davis et al., U.S. Overseas Military Presence: What Are the Strategic Choices? (Santa Monica, CA: RAND Corporation, 2012), 38.

19. David C. Kang characterizes South Korea's position on the East Asian fault line as "between balancing and bandwagoning," while Scott Snyder points out South Korea's modern-day strategic dilemma as "how to avoid circumstances that require choosing between the interests of Washington and Beijing." Both point out the pivot role that Seoul plays between the two giants. See David C. Kang, "Between Balancing and Bandwagoning: South Korea's Response to China," Journal of East Asian Studies, no. 9 (2009): 1-28; and Scott Snyder, "Korea, between China and United States," in Asia's Middle Powers? The Identity and Regional Policy of South Korea and Vietnam, ed. Joon-Woo Park, Gi-Wook Shin, and Donald W. Keyser (Stanford, CA: Walter H. Shorenstein Asia-Pacific Research Center, Stanford University, 2013).

20. There was an abrupt shift in the Philippines' position after the June 2016 inauguration of President Rodrigo Duterte, whose tirades against the United States and friendly gestures toward Beijing seem at odds with Manila's traditional role between the United States and China. Whether the Philippines will stay in that course is highly dubious, given the overwhelming influence of the United States in the country, and particularly the close ties between the two militaries and governments.

21. Yu-Shan Wu, "Under the Shadow of a Rising China: Convergence towards Hedging and the Peculiar Case of Taiwan," in Globalization and Security Relations across the Taiwan Strait: In the Shadow of Power, ed. Ming-chin Monique Chu and Scott L. Kastner (Oxon: Routledge, 2014).

22. "Stay" and "exit" suggest two opposite strategies by Taiwan with regard to mainland China. "Stay" means to remain in the framework of "one China" and agree to disagree with Beijing as to the meaning of that one China. Under this formula, Taipei insists that the one China is the Republic of China, while Beijing insists that it is the People's Republic of China. Neither side imposes its position on the other; both agree to "one China, differing interpretations." This compromise is embodied in the 1992 Consensus. "Exit" means to break away from the "one China" framework and to sever legal bonds with mainland China. The hard version of this advocates abolishing the ROC and launching a new and independent nation, the Republic of Taiwan. The soft version is content with severing legal bonds with mainland China without changing the name of the country. For them the ROC is Taiwan. Both versions of the "exit" strategy seek "Taiwan independence."

23. For an in-depth analysis of the four forces, see Bao Tzong-Ho and Wu Yu-Shan, eds., Zhengbian zhongde liang'an guanxi lilun [Contending theories on cross-Strait relations] (Taipei: Wu-nan, 1999); and Bao Tzong-Ho and Wu Yu-Shan, eds., Chongxin jianshi zhengbian zhongde liang'an guanxi lilun [Revisiting theories on cross-Strait relations], 2nd ed. (Taipei: Wu-nan, 2012). 
24. On the recognition of divided nations and its application to cross-Strait relations, see Yung Wei, "Recognition of Divided States: Implication and Application of Concepts of 'Multi-system Nations,' 'Political Entities', and 'Intra-National Commonwealth,' International Lawyer 34, no. 3 (2000): 997-1011; and Shaocheng Tang, "A Comparison between Intra-German Relations in the 1970s and Cross-Strait Relations since 2008," Issues and Studies 46, no. 4 (2010): 1-36.

25. There is a large literature on economic integration and its impact on conflict mitigation and political amalgamation. For economic integration and cross-Strait relations, see Carl Clark, "Does European Integration Provide a Model for Moderating Cross-Strait Relations?" Asian Affairs 29, no. 4 (2003): 195-215; Mikael Mattlin, "Structural and Institutional Integration: Asymmetric Integration and Symmetricity Tendencies," Cooperation and Conflict 40, no. 4 (2005): 403-21; Shu Keng, "Understanding Integration and 'Spillover' across the Taiwan Strait," in Taiwanese Identity in the Twenty-First Century, ed. Gunter Schubert and Jens Damm (Oxon: Routledge, 2011).

26. For power asymmetry theories, see Yu-Shan Wu, Kangheng huo hucong-liang'an guanxi xinquan: cong qian Sulian kan Taiwan yu Dalu jian de guanxi [Balancing or bandwagoning: Cross-Straits relations in view of the former Soviet Union] (Taipei: Cheng-chung, 1997); Yu-Shan Wu, "Quanli buduicheng yu liangan guanxi yanjiu" [Power asymmetry and the study of cross-Strait relations], in Bao Tzong-Ho and Wu Yu-Shan, Chongxin jianshi zhengbian zhongde liang'an guanxi lilun; Brantly Womack, "China and Southeast Asia: Asymmetry, Leadership and Normalcy," Pacific Affairs 76, no. 4 (2003/2004): 529-48; and Womack, China and Vietnam.

27. For the vast literature on the identity shift in Taiwan, see T. Y. Wang and I-Chou Liu, "Contending Identities in Taiwan: Implications for Cross-Strait Relations," Asian Survey 44, no. 4 (2004): 568-90; Gunter Schubert, "Towards the End of a Long Journey: Assessing the Debate on Taiwanese Nationalism and National Identity in the Democratic Era," ASIEN, no. 98 (2006): 26-44; Shelley Rigger, "Looking toward the Future in the Taiwan Strait: Generational Politics in Taiwan," SAIS Review 31, no. 2 (2011): 65-77; Rou-lan Chen, "Beyond National Identity in Taiwan: A Multidimensional and Evolutionary Conceptualization," Asian Survey 52, no. 5 (2012): 845-71; and Rou-lan Chen, “Taiwan's Identity in Formation: In Reaction to a Democratizing Taiwan and a Rising China," Asian Ethnicity 14, no. 2 (2013): 229-50.

28. For elections and Taiwan's mainland policy, see Yu-Shan Wu, "Taiwan's Domestic Politics and Cross-Strait Relations," China Journal, no. 53 (2005): 35-60; Yu-Shan Wu, "The Evolution of the KMT's Stance on the One China Principle," in Schubert and Damm, Taiwanese Identity; and Richard Bush, Untying the Knot: Making Peace in the Taiwan Strait (Washington, DC: Brookings Institution Press, 2005), 142-98.

29. For the role played by the United States, see Cheng-yi Lin, "A Status Quo with Different Interpretations: Taiwan, China, the United States, and Security in the Taiwan Strait," in The Future of United States, China, and Taiwan Relations, ed. Cheng-yi Lin and Denny Roy (New York: Palgrave Macmillan, 2011); and Nancy Tucker, "Strategic Ambiguity or Strategic Clarity?" in Dangerous Strait: The U.S.Taiwan-China Crisis, ed. Nancy Tucker (New York: Columbia University Press, 2005).

30. Although one cannot equate Russian speakers with Russophiles or Russia identifiers, Russianspeaking Ukrainians are psychologically close to Russia and view Ukrainian nationalism with suspicion. Their identity can be characterized as "East Slavonic." The cleavage between the eastern and western parts of Ukraine has deep historical roots in how the country was incorporated into the Russian Empire/Soviet Union by stages, with the eastern provinces joining Russia as early as 1654 (Treaty of Pereyaslav), and the westernmost territories falling into the Soviet hands as late as 1945 . The eastern part of the country was heavily Russified, while the western part was under the influence of Poland and Austro-Hungary.

31. For a discussion of Ukraine's economic integration with Russia and its political implications, see Celeste A. Wallander and Robert Legvold, "Economics and Security in the Post-Soviet Space," in 
Swords and Sustenance: The Economics of Security in Belarus and Ukraine, ed. Robert Legvold and Celeste A. Wallander (Cambridge, MA: American Academy of Arts and Sciences, 2004).

32. Both Taiwan and Ukraine adopted a semipresidential constitutional framework, in which the president typically wields ultimate power: Taiwan has remained in that constitutional framework since 1997, while Ukraine had a dominant president from 1996 to 2004, and again from 2010 to 2014. As a result, Taiwan's mainland policy and Ukraine's Russia policy are determined by their presidents, and the change of president has often brought about the most dramatic shifts of the country's policy toward its powerful neighbor. For the constitutional structure of Taiwan, see Yu-Shan Wu, "Semipresidentialism-Easy to Choose, Difficult to Operate: The Case of Taiwan," in Semi-presidentialism outside Europe: A Comparative Study, ed. Robert Elgie and Sophia Moestrup (Oxon: Routledge, 2011). For Ukraine's unstable presidentialism, see Sarah Birch, "Ukraine: Presidential Power, Veto Strategies and Democratisation," in Semi-presidentialism in Central and Eastern Europe, ed. Robert Elgie and Sophia Moestrup (Manchester, UK: Manchester University Press, 2008); Kimitaka Matsuzato, "Disintegrated Semi-presidentialism and Parliamentary Oligarchy in Post-Orange Ukraine," in Semipresidentialism and Democracy, ed. Robert Elgie, Sophia Moestrup, and Yu-Shan Wu (Basingstoke: Palgrave Macmillan). For the weak parliament of Ukraine (Verkhovna Rada), see Sarah Whitmore, State-Building in Ukraine: The Ukrainian Parliament, 1990-2003 (London: RoutledgeCurzon, 2004).

33. The first round of the presidential election in 2004 yielded no winner. The two forerunners, Viktor Yanukovych, the incumbent prime minister and favorite of President Kuchma, and Victor Yushchenko, a former prime minister and a staunch critic of the Kuchma regime, failed to garner an absolute majority, and a runoff election was scheduled. Despite popular expectations, Yanukovych was announced winner of the second-round election on November 22 by the Central Election Commission, setting off a popular protest led by Yushchenko. This was the start of the Orange Revolution that ultimately forced the Kuchma-Yanukovych camp to agree to annul the second-round voting and do a rerun on December 26, in which Yushchenko handsomely won by an 8 percent margin. For the Orange Revolution, see Anders Åslund and Michael McFaul, eds., Revolution Orange: The Origins of Ukraine's Democratic Breakthrough (Washington, DC: Carnegie Endowment for International Peace, 2006). For a comparison of "color revolutions" and their aftermaths, see Yu-Shan Wu, "Yanse geming de xunuo yu juxian" [The promises and limitations of color revolutions], Taiwan Democracy Quarterly 4, no. 2 (2007): 67-112.

34. Yanukovych's tilts between the EU and Russia came as a surprise to Moscow, given the president's long-standing pro-Russian posture. However, a looming economic crisis prompted Yanukovych to explore the role of a pivot. Even Alexander Lukashenko of Belarus, the staunchest ally of Russia, attempted to flirt with the West by making anti-Russian statements on the crisis of Ukraine. He said that Russia's annexation of Crimea created a "dangerous precedent" and that he was "categorically opposed" to the federalization of Ukraine, the Kremlin's favored option for the country's political development. During the Maidan Revolution, Lukashenko confirmed that Minsk was "extremely interested" in mending its relations with the European Union, and he even extended a welcome to Ukraine's acting president Oleksander Turchinov, a coup plotter in the eyes of the Kremlin. Lukashenko's flirtation with the Western position on Ukraine could lead Russia to buy back Belarus's loyalty, and it could also win him favors from the West. In short, he used ambiguity as a bargaining tool to reap benefits from both Russia and the West by attempting to play pivot. Of course, this strategy did not yield any substantive gains to Belarus, a pariah regime in the eyes of the EU. For Lukashenko's moves, see Gabrielle TétraultFarber, "Lukashenko Plays Both Sides in Ukraine Crisis," Moscow Times, April 22, 2014, www.themoscowtimes.com/news/article/lukashenko-plays-both-sides-in-ukraine-crisis/498724.html.

35. The fact that the West found itself in a bidding war with Russia over Ukraine shows a lack of understanding of Moscow's bottom line. Ukraine carries more strategic, economic, cultural, and ethnic significance for Russia than any other ex-Soviet republic. The possible expansion of NATO and the 
EU into Ukraine was bound to incur the most ferocious response from the leader of Russia, whoever that person might be. This point is driven home in John Mearsheimer, "Why the Ukraine Crisis Is the West's Fault: The Liberal Delusions That Provoked Putin," Foreign Affairs 93, no. 5 (September/October 2014): 77-89.

36. Putin's approval rating was in the low 60 s when the Ukrainian crisis erupted (November 2013). It surged to 80 percent when Crimea was annexed and managed to stay at that level. In October 2016 it stood at 84 percent. See Levada-Center, "Approval of Vladimir Putin," regularly updated, www.levada. ru/eng/, accessed November 1, 2016. 